\title{
Quantitative studies of food protein degradation and the energetic efficiency of microbial protein synthesis in the rumen of sheep given chopped lucerne and rolled barley
}

\author{
BY J. C. MATHERS AND E. L. MILLER \\ Department of Applied Biology, University of Cambridge, Pembroke Street, \\ Cambridge CB2 3DX
}

(Received 29 August 1980 - Accepted 9 January 1981)

1. In a randomized block design, four sheep were given $800 \mathrm{~g}$ daily of diets containing: chopped lucerne (L), chopped lucerne-rolled barley $(2: 1$; LB), rolled barley-chopped lucerne $(2: 1 ; \mathrm{BL})$, rolled barley (B); each diet was supplemented with minerals, vitamins and urea as considered necessary. Chromic oxide was included in the diets as a flow marker.

2. Flows of organic matter (OM) and non-ammonia-nitrogen (NAN) to the small intestine (SI) were measured and microbial protein was identified by a ${ }^{35} \mathrm{~S}$-incorporation procedure.

3. OM disappearance in the rumen increased linearly with increasing inclusion of barley in the diet but there was no significant change in microbial NAN flow to the SI so that the yield of microbial NAN (g)/ $\mathrm{kg}$ fermented OM (FOM) decreased from 29.6 (diet L) to 22.7 (diet B). Changes in the energetic efficiency of microbial protein synthesis appeared to be unrelated to alterations in rumen fluid volatile fatty acid (VFA) proportions or in rumen fluid dilution rate (D).

4. The degradability of dietary protein (non-urea-N), estimated using the ${ }^{35} \mathrm{~S}$ procedure, was $0.72,0.76,0.86$ and 0.86 for diets $\mathrm{L}, \mathrm{LB}, \mathrm{BL}$ and B respectively. Similar values were obtained from concurrent polyester-bag experiments when the fractional outflow rate of undegraded protein from the rumen $(k)$ was assumed to be $0 \cdot 046$.

Current procedures for evaluating foods as sources of nitrogen for ruminants (digestible crude protein $(\mathrm{N} \times 6.25)$ and available protein, Agricultural Research Council, 1965) have proved to be inadequate and alternative procedures have recently been proposed by workers in several countries (Journet \& Vèrité, 1977; Roy et al. 1977; Satter \& Roffler, 1977). These new schemes recognize that protein flowing to the small intestine (SI) of the ruminant consists largely of microbial protein synthesized in the rumen and of food protein which has escaped rumen degradation. For their validity, all the new schemes rely upon accurate prediction of both the yield of microbial protein and of the proportion of food protein escaping to the SI.

Undoubtedly much of the variation in the yield of microbial $\mathbf{N}$ per unit organic matter (OM) disappearing in the rumen (see review by Thomas, 1973) is due to the experimental difficulties inherent in making such measurements and to the different techniques used to identify microbial protein and to measure digesta flow-rates. However there have been suggestions that the energetic efficiency of microbial synthesis is not constant and that it may vary systematically with alterations in the proportions of structural carbohydrates and starch in the ration (McMeniman et al. 1976; Offer et al. 1978). Such variation in efficiency of microbial growth might be the result of changes in the yield of ATP from carbohydrate fermentation to volatile fatty acids (VFA) as indicated by differences in the proportions of the individual VFA endproducts (Hume, 1970; Ishaque et al. 1971) or by changes in the efficiency of use of ATP (Harrison et al. 1975; Kennedy et al. 1976).

The present study was designed to investigate the effects of varying the diet of sheep from all roughage (chopped lucerne) to all concentrate (rolled barley) on the energetic efficiency of microbial protein yield. The diets provided a wide range of intakes of structural carbohydrates and starch and it was assumed that microbial protein yield was limited only 
by the availability of energy as the diets were formulated to provide adequate quantities of all factors known to be required for microbial growth. It was found that the yield of microbial non-ammonia-N (NAN)/unit fermentable OM (FOM) decreased linearly with increases in barley intake and reasons for these changes were explored. In addition, estimates of the degradability of dietary protein in the rumen were obtained by conventional procedures (Mathers \& Miller, 1980) and compared with estimates from the polyester bag technique (Ørskov \& Mehrez, 1977; Mathers et al. 1977).

A brief account of part of this work has been presented (Mathers \& Miller, 1977).

EXPER I MENT AL

Animals and management

Four cross-bred wether sheep approximately 15 months of age and weighing 24-34 kg were used. At least 2 months before this study, each animal was fitted with permanent rumen and duodenal cannulas; the latter was a single cannula (Ash, 1962) placed approximately $50 \mathrm{~mm}$ from the pyloric sphincter. The sheep were held in metal metabolism cages in a room under continuous illumination. Ambient temperatures varied from 21.5 to $29.5^{\circ}$ during the experiment.

\section{Diets and feeding}

The major dietary components were rolled barley and chopped dried lucerne (Medicago sativa). The latter had been artificially dried and was purchased as cobs which were broken up by passage through a hammer mill without a screen. A similar batch of chopped lucerne from the same source had a modulus of uniformity of 9:1:0 and a modulus of fineness of 5.56 (American Society of Agricultural Engineers, 1967). Four diets consisting of: all lucerne (L), lucerne-barley $(2: 1$; LB), barley-lucerne $(2: 1 ; \mathrm{BL})$ and all barley (B) were formulated. The quantities of dietary components offered daily to the sheep were ( $\mathrm{g}$ fresh weight): chopped lucerne 760 (diet L), chopped lucerne 507+ rolled barley 253 (diet LB), chopped lucerne 253 + rolled barley 507 (diet BL) and rolled barley 760 (diet B). In addition, sheep on all diets received $40 \mathrm{~g}$ daily of premixes which supplied minerals and trace elements (g/d): $\mathrm{Na}_{2} \mathrm{SO}_{4} 4, \mathrm{NaCl} 3 \cdot 1, \mathrm{MgCO}_{3} 1 \cdot 5, \mathrm{FeSO}_{4} 0 \cdot 12, \mathrm{MnSO}_{4} .4 \mathrm{H}_{2} \mathrm{O} 0 \cdot 16, \mathrm{ZnO} 0 \cdot 048$, $\mathrm{CoSO}_{4} \cdot 7 \mathrm{H}_{2} \mathrm{O} 0 \cdot 03, \mathrm{CaIO}_{3} 0 \cdot 0016, \mathrm{NaMo}_{4} \cdot 2 \mathrm{H}_{2} \mathrm{O} 0 \cdot 0016$, plus stabilized vitamins equivalent to $(\mathrm{mg} / \mathrm{d})$ : retinyl acetate $2 \cdot 75$, cholecalciferol $0 \cdot 04, \mathrm{D}, \mathrm{L} \alpha$-tocopherol 32 , plus chromic oxide $4 \mathrm{~g} / \mathrm{d}$. The diets were made isonitrogenous by addition of urea $(\mathrm{g} / \mathrm{d}): 0$ (diet $\mathrm{L}$ ), $3 \cdot 2$ (diet LB), 6.4 (diet BL) and 9.6 (diet B) and the premixes were made to $40 \mathrm{~g}$ with molassine meal (The Molassine Company Ltd, London SE10 OPU). All diets were offered as loose combinations at 2 hourly intervals by mechanical feeders (A. Overhill, Cambridge). Water was available $a d$. lib.

\section{Experimental design and experimental schedule}

Each diet was offered to each sheep for $15 \mathrm{~d}$ using a randomized block design in which the four sheep received the diets in the following order: B, L, LB, BL (sheep 1), LB, BL, B, L (sheep 2), B, L, LB, BL (sheep 3) and BL, LB, B, L (sheep 4). During each experimental period, the following schedule was followed: day 1, sheep weighed, shorn and inspected; days 8-9, polyester bag experiment; days $9-14,{ }^{35} \mathrm{SO}_{4}$ infusion to rumen; days 12-14, collection of rumen and duodenal samples; days 11-15, faecal collection; day 15, determination of rumen fluid dilution rate.

Polyester bag experiment. Estimates of the rate and extent of food protein degradation in the rumen were obtained using the polyester bag technique outlined by Mathers $e t$ al. (1977) except that the pore sizes of the bags used varied between approximately 45 and $100 \mu \mathrm{m}$ and that the major dietary components were ground to pass a $2.5 \mathrm{~mm}$ screen (Ørskov \& Mehrez, 1977). 
Digestibility measurements. Faeces were collected into polyethylene bags which were fastened over the rear of each sheep and held in position with the aid of a light webbing harness. Portions $(0 \cdot 25)$ of the daily excretion were bulked, mixed, dried at $100^{\circ}$ and ground before analysis for dry matter (DM), N, OM and chromic oxide.

Estimation of microbial protein in duodenal digesta. The ${ }^{35} \mathrm{~S}$-incorporation procedure of Mathers \& Miller (1980) was used. Approximately $200 \mu \mathrm{Ci} \mathrm{Na}{ }_{2}^{35} \mathrm{SO}_{4}$ in 21 water were infused continuously each day for $5 \mathrm{~d}$ to the rumen. From digesta collected on days 3-5 of ${ }^{35} \mathrm{~S}$ infusion, the proportion of microbial NAN in digesta NAN was determined as the ${ }^{35} \mathrm{~S}:$ NAN of whole digesta divided by the ${ }^{35} \mathrm{~S}: \mathrm{NAN}$ of a microbial fraction isolated from duodenal digesta.

Measurement of rumen fluid volume and dilution rate $(D)$. CrEDTA was prepared as described by Downes \& $\mathrm{McD}$ onald (1964) except that no ${ }^{51} \mathrm{CrCl}_{3}$ was added and that excess chromic ions were precipitated by addition of sodium hydroxide rather than ammonium hydroxide. CrEDTA solution $(100 \mathrm{ml})$ was injected into the rumen and five samples of rumen fluid were collected at approximately hourly intervals thereafter.

Collection of rumen and duodenal samples. Rumen fluid was withdrawn twice daily for $3 \mathrm{~d}$ with the aid of a slightly-modified $60 \mathrm{ml}$ disposable syringe attached to a sampling tube which dipped into the rumen contents. $\mathrm{pH}$ was measured immediately and subsamples $(5 \mathrm{ml})$ were taken for estimation of ammonia, lactate and VFA concentrations and sulphide specific activity (SA). Subsamples for ammonia determination were preserved by mixing with $5 \mathrm{ml} 1 \mathrm{M}$-hydrochloric acid, those for lactate and VFA by mixing with $1 \mathrm{ml}$ deproteinizing solution (metaphosphoric acid (250 g/l)-1 M-crotonic acid $(4: 1, \mathrm{v} / \mathrm{v})$ ) and those for sulphide SA by mixing with $0.2 \mathrm{ml}$ cadmium acetate solution $(50 \mathrm{~g} / \mathrm{l})$ and three drops octanol (Gawthorne \& Nader, 1976). To allow calculation of the flow of microbial OM to the SI, a bacterial fraction was isolated from rumen fluid (Mathers \& Miller, 1980) of sheep on each diet and analysed for $\mathrm{N}$ and $\mathrm{OM}$. Duodenal digesta was collected twice daily for $3 \mathrm{~d}$ by a modification of the procedure described by McDonald (1948). A urethral catheter was inserted into the duodenal cannula so that the balloon end passed towards the distal intestine and the balloon came to rest just beyond the foot of the cannula. The balloon was inflated with $5 \mathrm{ml}$ water and blocked the intestine. Digesta flowing from the abomasum was diverted out through the cannula and was collected in a disposable colostomy bag (Down Bros. and Mayer and Phelps Ltd, Surrey). Digesta was collected for 0.5-1.0 h and during this time, a salt solution was pumped at approximately $175 \mathrm{ml} / \mathrm{h}$ via the urethral catheter to the distal intestine. The salt solution which contained $(\mathrm{g} / \mathrm{l})$ : sodium chloride $2 \cdot 99$, disodium hydrogen phosphate $2 \cdot 57$, potassium chloride $2 \cdot 00$, sodium acetate $1 \cdot 76$, acetic acid (glacial) $1 \cdot 3, \mathrm{MgCl}_{2} .6 \mathrm{H}_{2} \mathrm{O} 0.83$ and calcium chloride 0.75 was adjusted to $\mathrm{pH} 3.0$ by addition of approximately $4 \mathrm{~g} / \mathrm{l}$ concentrated hydrochloric acid. Immediately following collection of digesta, a microbial fraction was isolated by differential centrifugation (Mathers \& Miller, 1980) and the remaining whole digesta was freeze-dried before analysis for $\mathrm{N}$, ammonia-N, $\mathrm{Cr}_{2} \mathrm{O}_{3}, \mathrm{OM}$ and ${ }^{35} \mathrm{~S}: \mathrm{NAN}$.

\section{Analytical procedures}

$\mathrm{N}$, ammonia, $\mathrm{Cr}_{2} \mathrm{O}_{3}$ and ${ }^{35} \mathrm{~S}: \mathrm{NAN}$ determinations were made as described previously (Mathers \& Miller, 1980). DM was determined by drying at $100^{\circ}$ for $24 \mathrm{~h}$ and $\mathrm{OM}$ as DM less the residual ash obtained after heating at $550^{\circ}$ for $16 \mathrm{~h}$. Sulphide was isolated from rumen fluid using the gas-transfer apparatus described by Donaghey (1976) except that the $30 \mathrm{ml}$ tube on the side arm was replaced by a $50 \mathrm{ml}$ Quickfit flask. Sulphide released by acidification ( $6 \mathrm{ml} 6 \mathrm{M}-\mathrm{HCl}$ ) was trapped by $30 \mathrm{ml}$ sulphide-absorbing solution $(16.7 \mathrm{~g}$ zinc acetate and $4.2 \mathrm{~g}$ sodium acetate/l) contained in the side-arm flask. This was mixed with $10 \mathrm{ml} p$-aminodimethyl aniline (pADMA) solution $(0.75 \mathrm{~g} \mathrm{pADMA} . \mathrm{HCl}$ and $200 \mathrm{ml}$ 
concentrated $\left.\mathrm{H}_{2} \mathrm{SO}_{4} / 1\right)$ and the characteristic methylene blue colour developed by addition of $2 \mathrm{ml}$ ferric ammonium sulphate (FAS) solution (125 g FAS and $25 \mathrm{ml}$ concentrated $\mathrm{H}_{2} \mathrm{SO}_{4} / \mathrm{l}$ ) (Johnson \& Nishita, 1952). The mix ture was made up to $100 \mathrm{ml}$ with distilled water and the absorbance read at $660 \mathrm{~nm}$ in a spectrophotometer (SP 600; Pye Unicam Ltd, Cambridge). Radioactivity associated with sulphide was determined as follows: $7.5 \mathrm{ml}$ methylene blue solution was decolorized by mixing with $0.5 \mathrm{ml}$ saturated ascorbic acid solution in a scintillation vial, $7 \mathrm{ml}$ PCS solubilizer and liquid scintillation fluid (Hopkin and Williams, Romford, Essex) was added and the mixture counted in a Corumatic 200 liquid-scintillation spectrometer (Tracerlab GB Ltd, Weybridge, Surrey). Total lactic acid in rumen fluid was determined by the method of Barker \& Summerson (1940) as modified by Pennington \& Sutherland (1956) and L-lactic acid by a commercial enzyme assay (Boehringer Corporation (London) Ltd, Lewes, East Sussex). D-lactic acid was assumed to be total lactic acid minus L-lactic acid. VFA were separated and measured by gas-liquid chromatography using a column of $100 \mathrm{~g}$ Carbowax 20M-TPA $/ \mathrm{kg}$ Diatomite C-AW 60-70 mesh (JJs (Chromatography) Ltd, Hardwick Trading Estate, Kings Lynn). Crotonic acid was used as an internal standard and formic acid vapour was included in the carrier gas to improve separation of the VFA. The chromium as CrEDTA in rumen fluid was assayed by atomic absorption spectroscopy (Evans Electroselenium Ltd, Halstead, Essex).

\section{Statistical analysis}

Values were examined by analysis of variance in which the linear and quadratic effects of diet were separated by orthogonal polynomials and where significant $(P<0.05)$ effects were observed, response curves were fitted (Ridgman, 1975). For digesta samples where observations were made twice daily for $3 \mathrm{~d}$ on each sheep on each diet, some observations were missing and under such circumstances, the values were analysed using appropriately weighted means as there was little evidence of systematic variation with time (Rowell \& Walters, 1976).

\section{Polyester bag experiments}

Values from the polyester bag experiments were used in various assays to estimate the degradability of dietary protein (non-urea-N).

Model A. Following Ørskov \& Mehrez (1977), the extent of protein degradation was assumed to be equal to the proportion of $\mathrm{N}$ disappearing from the polyester bag at that time when $90 \%$ of the digestible DM (estimated from the in vivo digestibility study, see Fig. 1) had disappeared from the bag.

Model B. The curve of disappearance of protein $(p)$ from the polyester bag with time in the rumen $(t)$ was described by a single exponential equation of the form:

$$
p=a+b\left(1-e^{-c t}\right)
$$

where $a, b$ and $c$ are constants fitted by an iterative least squares procedure. The model was constrained so that $a+b$ did not exceed $100 \%$ (Ørskov \& McDonald, 1979). Then assuming values for the fractional outflow rate from the rumen of undegraded food protein $(k)$, the degradability of dietary protein $(P)$ was calculated as:

$$
P=a+\frac{b c}{c+k}
$$

Ørskov \& McDonald (1979) have shown that the rumen incubation time $\left(t^{*}(\mathrm{~h})\right)$ in polyester bags which would yield the same protein degradability as would occur in practice may be calculated thus:

$$
t^{*}=\frac{1}{c} \ln [(c+k) / k]
$$




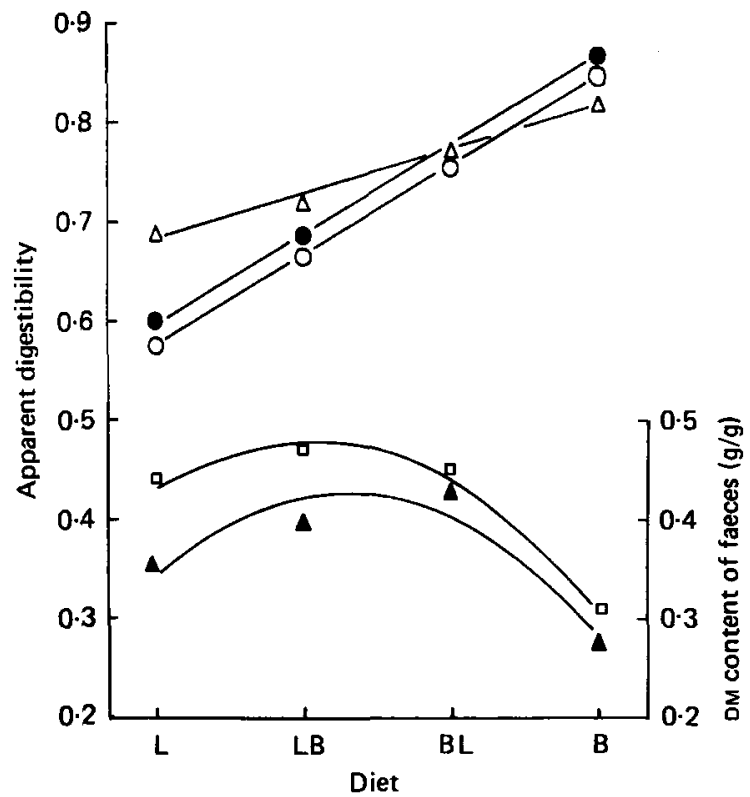

Fig. 1. Apparent digestibilities of dry matter $(O)$, organic matter $(O)$, nitrogen $(\Delta)$ and ash $(\Delta)$ and DM content $(\mathrm{g} / \mathrm{g})$ of faeces $(\square)$ in sheep given diets containing all lucerne $(\mathrm{L})$, lucerne-barley $(2: 1 ; \mathrm{LB})$, barley-lucerne $(2: 1 ; B L)$ and barley (B). For details of diets, see p. 588 . The lines shown have been drawn from significant orthogonal polynomials.

For the all barley diet, a double exponential equation of the form:

$$
p=a+b\left(1-e^{-c t}\right)+d\left(1-e^{-f t}\right),
$$

was also fitted to the curves of disappearance of $\mathrm{N}$ from the polyester bags where $a, b, c$, $d$ and $f$ are constants fitted by an iterative least squares procedure. From this the degradability of dietary protein was calculated as:

$$
P=a+\frac{b c}{c+k}+\frac{d f}{f+k}
$$

using an assumed value for $k$ as before.

Model $C$. This model, which requires simpler computation, is analogous to model $B$ when $a+b=100 \%$. A rate-constant for degradation $\left(k_{d}\right)$ was calculated as the slope of the natural logarithm of the $\mathrm{N}$ remaining in the polyester bag $v$. time in the rumen (Miller, 1980). Unlike the iterative procedure used with model B, fitting the linear regression to the logarithmically transformed data gives relatively more weight to observations at later times. With model $\mathrm{C}$, the degradability of dietary protein $(\mathrm{dg})$ was then calculated as:

$$
d g=a+(1-a) \frac{k_{d}}{k_{r}+k_{d}}
$$

where $a$ is the proportion of $\mathrm{N}$ disappearing from the bag at $t=0$ and $k_{r}$ is the rate constant for passage of undegraded protein from the rumen i.e. $k$ in Ørskov \& McDonald's (1979) notation. 
Table 1. pH and concentrations of volatile fatty acids (VFA), ammonia and lactic acids in rumen fluid of sheep given diets containing chopped lucerne and rolled barley

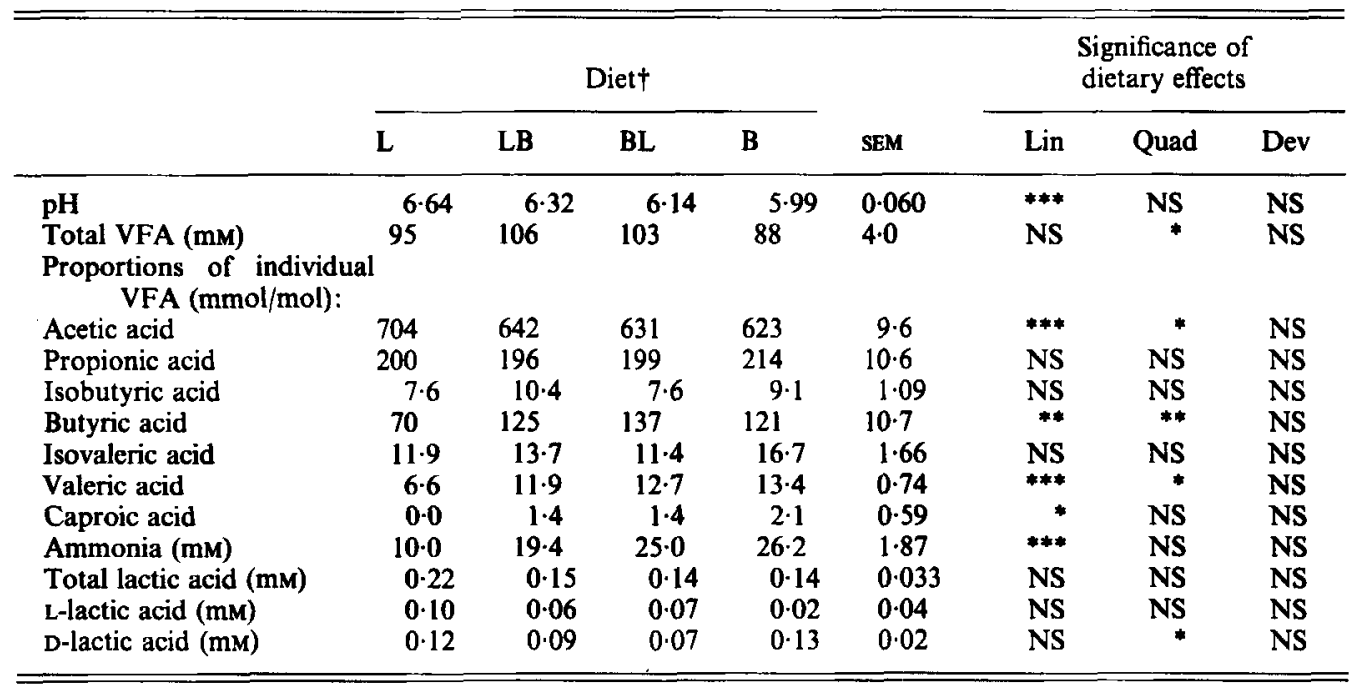

Lin, Quad, Dev, linear, quadratic and deviations from linear and quadratic effects of diet respectively; NS, not significant.

* $P<0.05$, ** $P<0.01, * * * P<0.001$.

$\dagger$ For details, see p. 588.

RESULTS

Apparent digestibility of diets

The apparent digestibility of DM, OM and $\mathrm{N}$ increased linearly $(P<0.01)$ as the diet was varied from diet $\mathrm{L}$ to diet $\mathrm{B}$ while that of ash varied quadratically with a maximum apparent digestibility on diet LB (Fig. 1). The concentration of DM in the faeces also varied quadratically as illustrated in Fig. 1.

\section{Rumen fermentation patterns}

Rumen fluid $\mathrm{pH}$ decreased linearly $(P<0.001)$ while ammonia concentration rose linearly $(P<0.001)$ as the proportion of barley and urea in the diet increased (Table 1). Total VFA concentration varied quadratically with diet reaching a maximum on diet LB. The molar proportions of propionic, isobutyric and isovaleric acids were unaffected by diet but that of acetic acid fell from $704 \mathrm{mmol} / \mathrm{mol}$ on diet $\mathrm{L}$ to $623 \mathrm{mmol} / \mathrm{mol}$ on diet $B$. The proportion of butyric acid increased quadratically as the proportion of barley in the diet increased reaching a maximum on diet BL. Caproic acid was not detected in the rumen fluid of animals given the all lucerne diet but the molar proportion of this acid increased linearly with increases in barley intake. On all diets, total lactic acid concentrations were relatively low and there were no significant $(P>0.05)$ changes in total or in L-lactic acid concentrations with changes in diet. However $D$-lactic acid concentration varied quadratically and showed a maximum on the all barley diet.

Rumen fluid volume and dilution rate and the flow of digesta from the rumen to the SI There were significant $(P<0.05)$ quadratic changes in rumen fluid volume with alterations in diet composition with the minimum mean volume on diet LB being $62 \%$ of that on diet B (Table 2). There was no relationship between rumen volume and flow of fluid from the 
Table 2. Rumen fluid volume and dilution rate and passage of digesta from the rumen to the small intestine of sheep given diets containing chopped lucerne and rolled barley

\begin{tabular}{|c|c|c|c|c|c|c|c|c|}
\hline & \multicolumn{4}{|c|}{ Diet† } & \multirow[b]{2}{*}{ SEM } & \multicolumn{3}{|c|}{$\begin{array}{l}\text { Significance of } \\
\text { dietary effects }\end{array}$} \\
\hline & $\mathbf{L}$ & LB & BL & B & & Lin & Quad & Dev \\
\hline Rumen fluid volume (1) & $5 \cdot 8$ & $3 \cdot 8$ & $4 \cdot 3$ & $6 \cdot 2$ & 0.79 & NS & $*$ & NS \\
\hline Dilution rate $(\mathrm{vol} / \mathrm{h})$ & 0.06 & 0.15 & 0.09 & 0.09 & 0.024 & NS & NS & NS \\
\hline $\begin{array}{l}\text { Flow of fluid from } \\
\text { rumen }(\mathrm{ml} / \mathrm{h})\end{array}$ & 335 & 558 & 369 & 449 & $63 \cdot 4$ & NS & NS & $*$ \\
\hline $\begin{array}{l}\text { Flow of digesta to } \\
\text { duodenum }(\mathrm{g} / \mathrm{h}) \ddagger\end{array}$ & 733 & 663 & 498 & 497 & $77 \cdot 1$ & * & NS & NS \\
\hline Duodenal digesta $\mathrm{pH}$ & $2 \cdot 90$ & $2 \cdot 79$ & $2 \cdot 60$ & 2.66 & 0.057 & ** & NS & NS \\
\hline
\end{tabular}

Lin, Quad, Dev, linear, quadratic and deviations from linear and quadratic effects of diet respectively; NS, not significant.

$* P<0.05, \quad * * P<0.01, \quad * * * P<0.001$

$\dagger$ For details, see p. 588.

$\ddagger$ Calculated from weight of digesta collected at the duodenal cannula in a known period of time.

Table 3. Sulphur metabolism in and estimation of microbial protein flow from the rumen of sheep given diets containing chopped lucerne and rolled barley

\begin{tabular}{|c|c|c|c|c|c|c|c|c|}
\hline & \multicolumn{4}{|c|}{ Diet $†$} & \multirow[b]{2}{*}{ SEM } & \multicolumn{3}{|c|}{$\begin{array}{l}\text { Significance of } \\
\text { dietary effects }\end{array}$} \\
\hline & L & LB & BL & B & & Lin & Quad & Dev \\
\hline $\begin{array}{l}\text { Rumen fluid sulphide } \\
\text { concentration (mg S/l) }\end{array}$ & 12 & 13 & 12 & 11 & 1.8 & NS & NS & NS \\
\hline $\begin{array}{l}\text { SA rumen sulphide } \\
\text { (disintegrations/min } \\
\text { per g S) }\end{array}$ & 101 & 58 & 111 & 92 & $16 \cdot 7$ & NS & NS & * \\
\hline $\begin{array}{l}\text { SA duodenal microbial } \\
\text { isolate (disintegrations/ } \\
\text { min per mg NAN) }\end{array}$ & 4463 & 5328 & 5750 & 8036 & 393.9 & *** & NS & NS \\
\hline $\begin{array}{l}\text { Proportion of microbial } \\
\text { organically-bound } S \\
\text { derived from rumen } S^{2-t}\end{array}$ & 0.52 & 0.93 & 0.66 & 1.03 & 0.125 & $*$ & NS & * \\
\hline $\begin{array}{l}\text { SA whole duodenal } \\
\text { digesta (disintegrations/ } \\
\text { min per mg NAN) }\end{array}$ & 2958 & 4228 & 4977 & 6903 & $319 \cdot 1$ & $* * *$ & NS & NS \\
\hline $\begin{array}{l}\text { Proportion of duodenal } \\
\text { digesta NAN which is } \\
\text { microbial }\end{array}$ & 0.60 & 0.74 & 0.82 & 0.80 & 0.032 & $* *$ & $\bullet$ & NS \\
\hline $\begin{array}{l}\text { Proportion of infused } \\
\text { radioactivity incorporated } \\
\text { by micro-organisms } \|\end{array}$ & $0 \cdot 11$ & 0.17 & $0 \cdot 18$ & 0.24 & 0.018 & $* * *$ & NS & NS \\
\hline
\end{tabular}

NAN, non-ammonia-nitrogen; Lin, Quad, Dev, linear, quadratic and deviations from linear and quadratic effects of diet respectively; NS, not significant.

* $P<0.05,{ }^{* *} P<0.01$, *** $P<0.001$

+ For details, see p. 588.

¥ Assuming that microbial N:S was 11:1 (Walker \& Nader, 1968).

|| Calculated as described by Mathers \& Miller (1980). 
Table 4. Fermentation of organic matter $(O M)$ and food protein and synthesis of microbial protein in the rumen of sheep given diets containing chopped lucerne and rolled barley

\begin{tabular}{|c|c|c|c|c|c|c|c|c|}
\hline & \multicolumn{4}{|c|}{ Diet $\dagger$} & \multirow[b]{2}{*}{ SEM } & \multicolumn{3}{|c|}{$\begin{array}{l}\text { Significance of } \\
\text { dietary effects }\end{array}$} \\
\hline & L & LB & BL & B & & Lin & Quad & Dev \\
\hline OM intake (g/d) & 652 & 658 & 663 & 670 & - & - & - & - \\
\hline $\begin{array}{l}\text { OM apparently fermented } \\
\text { in rumen }(g / d)\end{array}$ & 263 & 286 & 337 & 403 & 15.9 & $* * *$ & NS & NS \\
\hline$N$ intake $(g / d)$ & $19 \cdot 6$ & $19 \cdot 5$ & $19 \cdot 4$ & $19 \cdot 3$ & - & - & - & - \\
\hline NUN intake $(\mathrm{g} / \mathrm{d})$ & $19 \cdot 6$ & 17.9 & $16 \cdot 1$ & $14 \cdot 3$ & - & - & - & - \\
\hline NAN flow to SI $(\mathrm{g} / \mathrm{d})$ & $17 \cdot 3$ & 17.8 & 15.7 & $15 \cdot 2$ & 0.98 & * & NS & NS \\
\hline $\begin{array}{l}\text { Microbial NAN flow } \\
\text { to SI }(\mathrm{g} / \mathrm{d})\end{array}$ & $10 \cdot 3$ & $12 \cdot 4$ & $12 \cdot 0$ & $12 \cdot 2$ & 0.65 & NS & NS & NS \\
\hline $\begin{array}{l}\text { Food NAN flow to SI } \\
(\mathrm{g} / \mathrm{d}) \ddagger\end{array}$ & 5.5 & 3.9 & $2 \cdot 0$ & 1.6 & 0.74 & ** & NS & NS \\
\hline $\begin{array}{l}\text { Proportion of food NUN } \\
\text { degraded in rumen }\end{array}$ & 0.72 & 0.76 & 0.86 & 0.86 & 0.048 & - & NS & NS \\
\hline N:ÖM rumen bacteria & $0 \cdot 12$ & 0.11 & 0.09 & $0 \cdot 10$ & - & - & - & - \\
\hline $\begin{array}{l}\text { Microbial OM flow to } \\
\text { SI }(\mathrm{g} / \mathrm{d})\end{array}$ & 86 & 111 & 134 & 121 & 6.8 & $* *$ & $*$ & NS \\
\hline FOM $(\mathrm{g} / \mathrm{d})$ & 351 & 397 & 471 & 527 & 16.5 & $* * *$ & NS & NS \\
\hline $\begin{array}{l}\text { Microbial NAN (g)/kg } \\
\text { FOM }\end{array}$ & 29.6 & $33 \cdot 1$ & $25 \cdot 4$ & $22 \cdot 7$ & $2 \cdot 19$ & * & NS & NS \\
\hline
\end{tabular}

NUN, non-urea nitrogen; NAN, non-ammonia-nitrogen; SI, small intestine; FOM, fermented OM, i.e. OM apparently fermented in rumen + microbial OM flow to SI; Lin, Quad, Dev, linear, quadratic and deviations from linear and quadratic effects of diet respectively; NS, not significant.

$* P<0.05, * * P<0.01, * * * P<0.001$.

+ For details, see p. 588.

$\ddagger$ Assuming $1.5 \mathrm{~g}$ endogenous NAN flow daily to SI (Phillipson, 1964; Harrop, 1974) and that all food urea was degraded to ammonia and carbon dioxide (Pearson \& Smith, 1943).

rumen. The dilution rate of rumen fluid (D) varied widely between sheep within diet and individual animals showed no consistent trends across diets so that between diet differences in $\mathbf{D}$ were not significant (Table 2). Estimates of the flow of fluid from the rumen were not significantly $(P>0.05)$ different from those of flow of digesta to the duodenum for barley-containing diets but digesta flow to the duodenum exceeded flow from the rumen for diet $\mathrm{L}$. The $\mathrm{pH}$ of duodenal digesta fell linearly as the proportion of barley in the diet increased.

\section{$S$ metabolism in the rumen}

Rumen sulphide concentrations were similar on all diets while the specific radioactivity (SA) of rumen sulphide showed a cubic response to diet with maximum and minimum values for diets BL and LB respectively (Table 3). The SA of the microbial isolate from duodenal digesta and the SA of whole duodenal digesta both increased linearly with increasing inclusion of barley in the diet (Table 3) but the rate of increase was greater for whole digesta. As an indication of the extent of de novo synthesis of S-containing amino acids, the proportion of microbial organically-bound $S$ which was derived from the sulphide pool was estimated and found to vary from 0.52 to 1.03 (Table 3). The proportion of infused ${ }^{35} \mathrm{~S}$ which flowed to the duodenum as organically-bound ${ }^{35} \mathrm{~S}$ increased linearly from $0 \cdot 11$ on diet $\mathrm{L}$ to 0.24 on diet $\mathrm{B}$. 


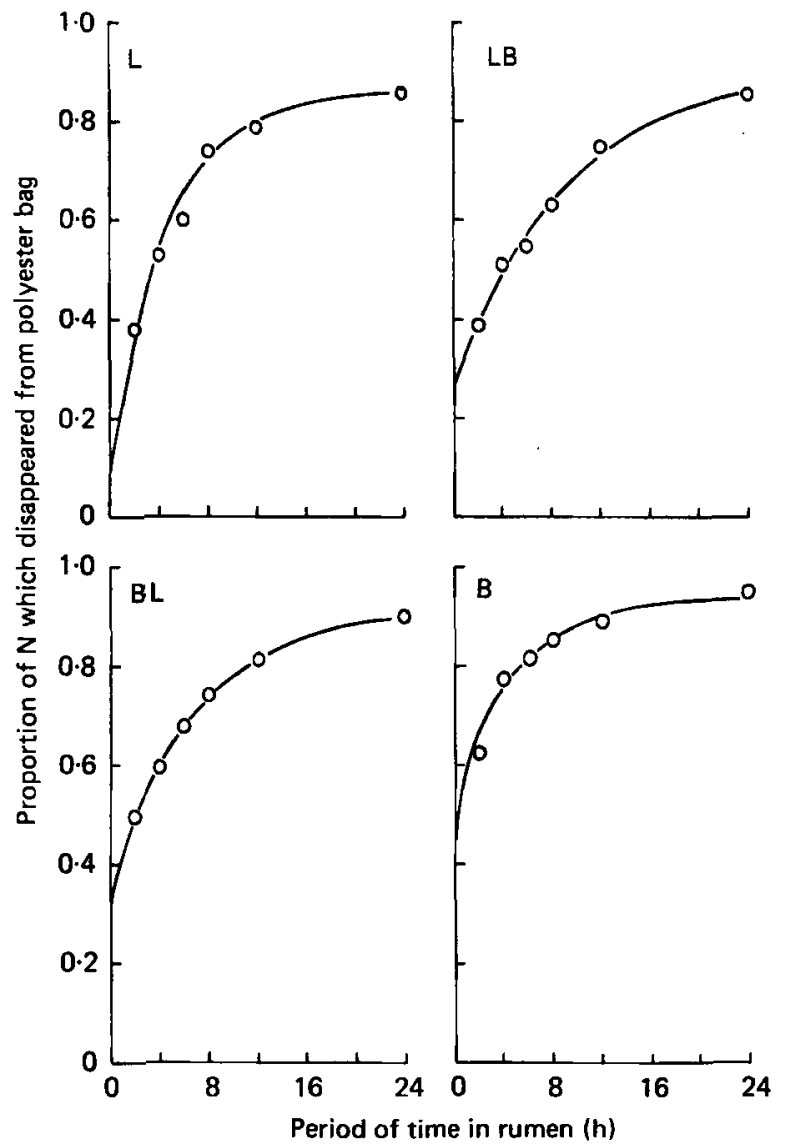

Fig. 2. Disappearance of nitrogen from all lucerne (L), lucerne-barley $(2: 1 ;$ LB), barley-lucerne $(2: 1$; $B L)$ and all barley (B) when incubated within polyester bags in the rumen of sheep over $24 \mathrm{~h}$ periods. For details of diets, see p. 588. The lines shown have been drawn from fitted equations of the form: $p=a+b\left(1-e^{-c t}\right)$ where $p$ is the proportion of protein which has disappeared from the bag, $t$ is the time (h) in the rumen, $a, b, c$ are constants using the coefficients given in Table 5. For details, see Ørskov \& McDonald (1979) and p. 590.

OM fermentation and protein transformations in the rumen

Because of the lower ash content of barley compared to lucerne $(20$ and $83 \mathrm{~g} / \mathrm{kg} \mathrm{DM}$ respectively), $\mathrm{OM}$ intakes were slightly higher on barley-containing diets (Table 4). OM apparently fermented in the rumen and truly fermented OM (FOM $=\mathrm{OM}$ apparently fermented + microbial OM flow to the SI) both increased linearly with increasing inclusion of barley in the diet but there were no significant $(P>0.05)$ changes in the daily yield of microbial NAN. Consequently, the estimated energetic efficiency of microbial protein synthesis ( $\mathrm{g}$ microbial NAN $/ \mathrm{kg}$ FOM) decreased linearly as the proportion of barley in the diet increased (see Table 4). Total and food NAN flows to the SI were lowest for the all barley diet and both increased linearly with increasing lucerne intake. The proportion of food protein (defined as non-urea-N) degraded in the rumen increased linearly from 0.72 for diet $\mathrm{L}$ to 0.86 for diet $\mathrm{B}$ with no indication of any interaction between the diets in the extent of protein degradation. 
Table 5. Estimates of the constants $\mathrm{a}, \mathrm{b}$ and $\mathrm{c}$ in the equation $\mathrm{p}=\mathrm{a}+\mathrm{b}\left(1-\mathrm{e}^{-\mathrm{ct}}\right)$ (where $\mathrm{p}$ is the disappearance of protein from the polyester bag $(\%), \mathrm{t}$ is the time $(h)$ in the rumen) fitted to the values of disappearance of nitrogen $(\%)$ from diets incubated in polyester bags within the rumen of sheep given diets containing chopped lucerne and rolled barley (see Fig. 2) and of the rumen incubation time ( $h$ ) which yields the same protein degradability as would occur in practice (t*) (see Orskov \& McDonald (1979) for derivation)

\begin{tabular}{|c|c|c|c|c|c|c|c|c|}
\hline \multirow[b]{2}{*}{ Parameter } & \multicolumn{4}{|c|}{ Diet $†$} & \multirow[b]{2}{*}{ SEM } & \multicolumn{3}{|c|}{$\begin{array}{l}\text { Significance of } \\
\text { dietary effects }\end{array}$} \\
\hline & L & LB & BL & B & & Lin & Quad & Dev \\
\hline$a$ & 12.8 & $26 \cdot 8$ & $33 \cdot 7$ & $45 \cdot 5$ & 6.44 & $* *$ & NS & NS \\
\hline $\bar{b}$ & $73 \cdot 5$ & $64 \cdot 2$ & $60 \cdot 4$ & $48 \cdot 3$ & $6 \cdot 19$ & - & NS & NS \\
\hline$c$ & 0.214 & $0 \cdot 108$ & 0.145 & 0.240 & 0.0237 & NS & $* * *$ & NS \\
\hline$t^{*}$ & $8 \cdot 3$ & $11 \cdot 2$ & $10 \cdot 2$ & $7 \cdot 6$ & 0.68 & NS & *** & NS \\
\hline
\end{tabular}

Lin, Quad, Dev, linear, quadratic and deviations from linear and quadratic effects of diet respectively; NS, not significant.

* $P<0.05, \quad * * P<0.01, * * * P<0.001$.

$\dagger$ For details, see p. 588.

\section{Polyester bag experiments}

Mean estimates of the extent of disappearance of food $\mathrm{N}$ from the polyester bags with time in the rumen are shown graphically in Fig. 2 with curves drawn from fitted single exponential equations (equation no. 1). Estimates of the constants $a, b$ and $c$ in such equations are given in Table 5. The sum of constants $a+b$ represents the total proportion of potentiallydegradable $\mathrm{N}$ in each diet and covered a small range from $86 \%$ of total $\mathrm{N}$ for lucerne to $94 \%$ for barley. Of this potentially-degradable protein, approximately $13 \%$ disappeared at $t=0$ with diet $\mathrm{L}$ while $49 \%$ disappeared with diet B. As a result, a much larger percentage $(85 \%)$ of the potentially-degradable lucerne $\mathrm{N}$ compared to $(57 \%)$ the barley $\mathrm{N}$ remained within the polyester bags to be acted on by microbial enzymes during the incubation period (Table 6). The fractional rate-constant for protein disappearance from the bags (c) varied quadratically with diet and was lower for mixtures of lucerne and barley than for either diet individually.

Food protein degradability was estimated from the 'polyester-bag' values in a number of ways as described above. In Table 6, these estimates are compared with those determined from analysis of duodenal digesta in which microbial protein was labelled with ${ }^{35} \mathrm{~S}$. Model A which is based on $\mathrm{N}$ disappearance when $90 \%$ of digestible DM has disappeared (Ørskov \& Mehrez, 1977) gave values for protein degradability which were much lower than those from the ${ }^{35} \mathrm{~S}$ method and usually lower than those calculated by alternative procedures (Table 6). Models B and $C$ required knowledge of the fractional outflow rate of undegraded food protein from the rumen ( $k$ or $k_{r}$ ) but unfortunately such measurements were not made in this study. Instead, $k$ and $k_{r}$ were assumed to be either 0.046 (Ørskov \& McDonald, 1979) or equal to the measured dilution rate of CrEDTA in the rumen (D; see Table 2). Assuming the value of 0.046 for $k$ and $k_{r}$, models B (using equation no. 2; Ørskov \& McDonald, 1979) and $C$ (using equation no. 6; Miller, 1980) both gave estimates of protein degradability which were similar to those from the ${ }^{35} \mathrm{~S}$ procedure. Where $\mathrm{D}$ was used as an estimate of $k$ or $k_{r}$, calculated protein degradabilities tended to be lower especially for diet LB than those determined using ${ }^{35} \mathrm{~S}$. There was little difference between estimates of protein degradability obtained using model $\mathrm{C}$ when all values or only values for the first $12 \mathrm{~h}$ of $\mathrm{N}$ disappearance were compared (Table 6). 


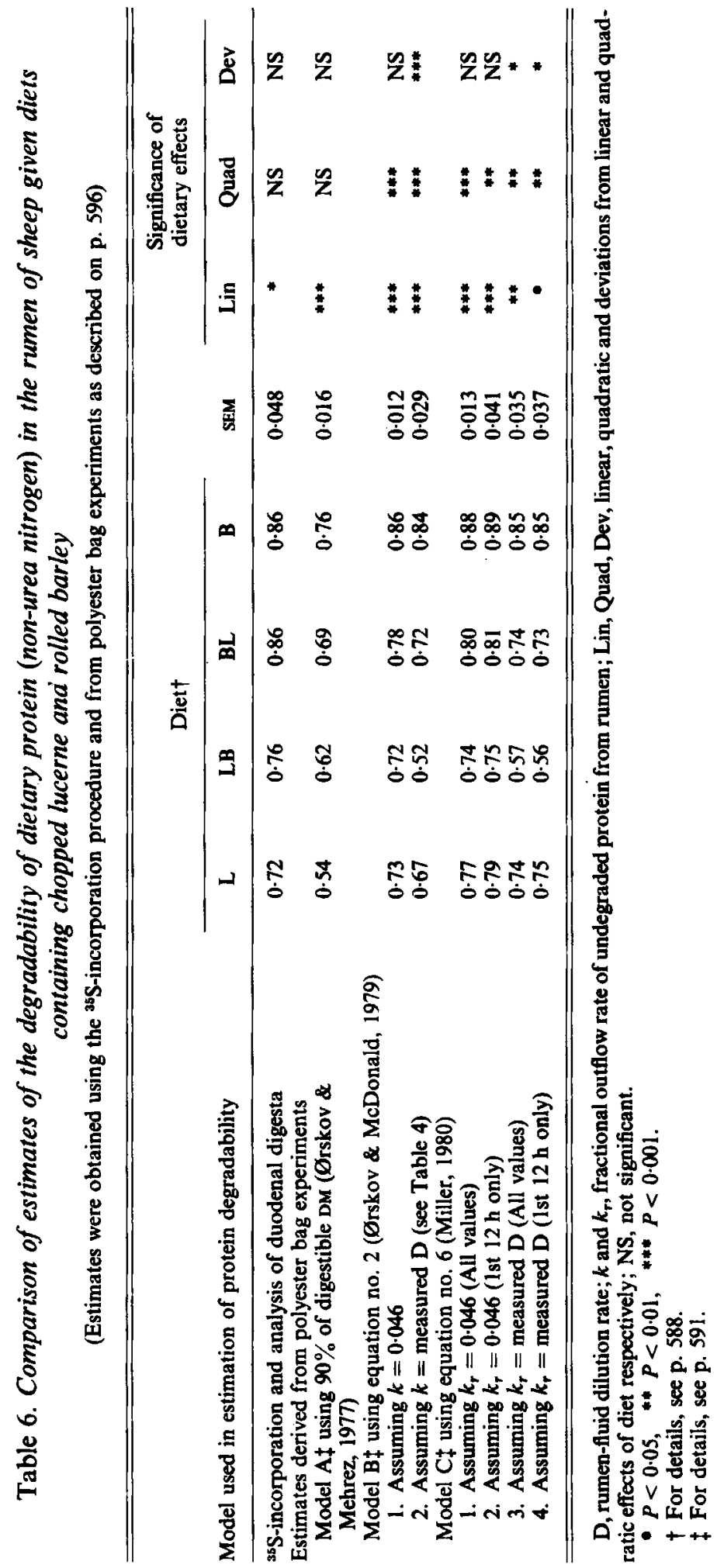


For barley only, the $\mathbf{N}$ disappearance values were also described by a double exponential equation (equation no. 4). In three out of four sheep, the double exponential model fitted better than the single ( $F(1,2)$ ranged from 7 to 48 ) but with the small number of degrees of freedom available for testing, the improvement was not significant $(P>0.05)$. The estimate of barley-protein degradability obtained using equation no. 5 was $0.86 \pm 0.024$ (mean $\pm \mathrm{SE}, r 4$ ) which is identical with those estimates obtained using ${ }^{35} \mathrm{~S}$ and from equation no. 2.

Using model B and equation no. 3, the rumen incubation time $\left(t^{*}\right)$ which would yield the same protein degradability as would occur in practice when these diets are consumed by similar animals varied quadratically with diet from a minimum of $7.6 \mathrm{~h}(\operatorname{diet} \mathrm{B})-11.2 \mathrm{~h}$ (diet LB) (Table 5).

\section{DISCUSSION}

The primary objectives of this study were to estimate the energetic efficiency of microbial protein synthesis and the extent of degradation of dietary protein in the rumen of sheep consuming diets consisting of various proportions of chopped lucerne and rolled barley. To ascertain whether the measurements were made under 'normal' conditions, several indices of rumen fermentation and digestibility were measured and the results compared with published work for similar foods. Many reports of the digestion of dried lucerne are available but there appears to be relatively little information about the digestibility of rolled barley given as the only food or of barley +lucerne mixtures.

\section{Digestibility and rumen fermentation}

The apparent digestibilities of DM, OM and $\mathrm{N}$ in diets $\mathrm{B}$ and $\mathrm{L}$ were similar to those reported for barley and lucerne by MacRae \& Armstrong (1969), Mathison \& Milligan (1971), Ørskov et al. (1971) and Thomson et al. (1972). Deviations from linearity in digestibility of $\mathrm{DM}, \mathrm{OM}$ and $\mathrm{N}$ with increasing inclusion of barley in the diet were very small (see Fig. 1) suggesting that associative effects between diets in digestibility of these components were negligible. Similar studies at the Feed Evaluation Unit, The Rowett Institute, Aberdeen also failed to detect any associative effects in digestibility of energy by sheep offered various cereals in combination with silages or dried forages at the maintenance level of feeding (Wainman, 1977). Conversely, there was a significant quadratic effect of diet composition on ash digestibility (see Fig. 1) indicating the presence of associative effects in digestibility of this component and confirming the observations of Church (1975). These effects and the observations that the proportion of DM in the faeces and the $\mathrm{N}$ content of faecal DM both varied quadratically with alterations in diet may be largely consequences of varying proportions of microbial matter in the faeces (Mason, 1969; Stephen \& Cummings, 1979, 1980).

Rumen fermentation patterns with diet L (Table 1) were typical of animals given dried lucerne (Thivend \& Journet, 1968; Thomson et al. 1972) but alterations in this pattern as the diet was changed to all barley were not as pronounced as those observed in sheep by Thivend \& Journet (1968) and in cattle by Sutton \& Johnson (1969). It is probable that the frequent feeding regimen and the moderate level of feeding used in the present experiment prevented the rapid fermentation of large quantities of starch and rapid falls in $\mathrm{pH}$ which might have resulted in the high propionate or lactate fermentations which are characteristic of animals given large amounts of cereals (Phillipson, 1952; Mann, 1970). In addition, the moderate level of feeding used in this experiment may have contributed to the lack of effect of diet on rumen fluid dilution rate (D; Table 2). However, there were large between sheep differences in $\mathrm{D}$ both within and between diets; similar variability has been reported by Egan et al. (1975), Harrison et al. (1975) and Kennedy et al. (1976). 
Table 7. Estimates of ATP production and efficiency of utilization in the rumen of sheep given diets containing chopped lucerne and rolled barley

\begin{tabular}{lcccc}
\hline \hline & \multicolumn{3}{c}{ Diet* $^{*}$} \\
\cline { 2 - 5 } & L & LB & BL & B \\
\hline ATP yield (mol/mol hexose fermented) & 4.5 & 4.4 & 4.4 & 4.4 \\
Nitrogen: DM rumen bacteria & 0.11 & 0.10 & 0.08 & 0.09 \\
$Y_{\text {ATP }}$ (g microbial DM/mol ATP) $\dagger$ & 10.1 & 11.9 & 12.0 & 9.9 \\
\hline \hline
\end{tabular}

DM, dry matter. * For details, see p. 588. + Calculated from truly-fermented OM.

Energetic efficiency of microbial growth in the rumen

The diets used in this experiment were designed to supply adequate quantities of all nutrients known to be required for microbial growth in the rumen so that available energy would be the limiting factor. On all diets, concentrations of ammonia (Table 1) and sulphide (Table 2) in rumen fluid were above the minimum concentrations usually considered adequate for maximal rates of microbial growth (Allen \& Miller, 1976; Mehrez et al. 1977; Hume \& Bird, 1970; Bray \& Till, 1975). Similarly, the accümulation of higher VFA in rumen fluid (Table 1) suggests that, with the possible exception of diet $L$ where caproic acid was not detected, the availability of these essential nutrients for some cellulolytic bacteria (Allison, 1965) is unlikely to have limited microbial growth. However, quantitative information on the requirements for these factors is scant.

The estimate of the energetic efficiency of microbial protein yield $29.6 \mathrm{~g} \mathrm{~N} / \mathrm{kg}$ FOM for the all lucerne diet is within the range of estimates $(24 \cdot 2-35 \cdot 2)$ for similar diets calculated from the results of Lindsay \& Hogan (1972) and Walker et al. (1975) while that for the all barley diet (22-7) is lower than the estimates $(26 \cdot 2-30 \cdot 0)$ for barley diets calculated from Mathison \& Milligan (1971), Ørskov et al. (1971) and Ling \& Buttery (1978). In this study the energetic efficiency of microbial protein synthesis declined linearly as the proportion of barley in the ration increased (Table 4) in agreement with the conclusion drawn by McMeniman et al. (1976). However, the highest yield of mirobial NAN/unit FOM was observed with diet $\mathrm{LB}$ which may indicate a synergistic effect of mixed dietary carbohydrates as suggested by Offer et al. (1978), Chamberlain \& Thomas (1979) and Hagemeister et al. (1981).

It is unlikely that variation in the yield of microbial NAN/unit FOM was due to variation in the yield of ATP. Conventional stoichiometric calculations using Leng's $(1970,1973)$ equations suggest that there would be little change in ATP yield with fermentation of different substrates to yield varying VFA proportions. Estimated ATP yields/mol hexose fermented for the observed VFA patterns in this experiment are given in Table 7 . The efficiency of use of ATP was estimated by calculating $Y_{\text {ATP }}$ ( $\mathrm{g}$ microbial DM/mol ATP; Table 7) using FOM as the appropriate estimate of the amount of hexose equivalent fermented to VFA. Estimates of $Y_{\mathrm{ATP}}$ for the all lucerne and all barley diets (10.1 and 9.9 respectively) were similar, which implies that relatively more ATP was used for synthesis of non-protein DM in the all barley diet and emphasizes the importance of variation in the chemical composition of microbial matter (see McAllan \& Smith, 1974, 1977; Czerkawski, 1976). However, synergism between dietary components was still apparent as diets LB and BL resulted in $20 \%$ higher efficiencies of use of ATP for microbial DM yield (Table 7).

In the present study there was no relationship between microbial growth efficiency, measured as microbial $\mathrm{N}(\mathrm{g}) / \mathrm{kg}$ FOM, and molar proportions of acetate, propionate or 
Table 8. In vivo estimates of the specific growth rate of mixed rumen micro-organisms/h $(\mu)$ and of the dilution rate of rumen fluid/h $(D)$

\begin{tabular}{|c|c|c|c|c|c|}
\hline Animal & Diet & $\begin{array}{l}\text { Isotopic } \\
\text { marker }\end{array}$ & $\mu$ & D & Reference \\
\hline $\begin{array}{l}\text { Cattle } \\
\text { Cattle } \\
\text { Sheep } \\
\text { Sheep } \\
\text { Calves } \\
\text { Sheep } \\
\text { Sheep } \\
\text { Sheep } \\
\text { Sheep }\end{array}$ & $\begin{array}{l}\text { Maize silage + concentrates } \\
\text { Maize silage+ concentrates } \\
\text { Grass hay } \\
\text { Rolled barley } \\
\text { Green oat } \\
\text { Wheaten straw chaff } \\
\text { Wheaten hay chaff } \\
\text { Clover hay } \\
\text { Chopped dried lucerne }\end{array}$ & $\begin{array}{l}{ }^{16} \mathrm{~N} \\
{ }^{15} \mathrm{~N} \\
{ }^{16} \mathrm{~N} \\
{ }^{15} \mathrm{~N} \\
{ }^{36 S} \\
{ }^{365} \\
{ }^{355} \\
{ }^{365} \\
{ }^{36} \mathrm{~S}\end{array}$ & $\begin{array}{l}0.039 \\
0.035-0.053 \\
0.024 \\
0.026 \\
0.104 \\
0.032 \\
0.042 \\
0.035 \\
0.054\end{array}$ & $\begin{array}{l}\bar{Z} \\
\overline{0.081} \\
0.068 \\
\overline{0} \\
0.070^{*} \\
0.071^{*} \\
0.108^{*} \\
0.060^{\dagger}\end{array}$ & $\begin{array}{l}\text { Ulbrich \& Scholz (1963) } \\
\text { Ulbrich \& Scholz (1966) } \\
\text { Mathison \& Milligan (1971) } \\
\text { Mathison \& Milligan (1971) } \\
\text { Singh et al. (1973) } \\
\text { Walker \& Nader (1975) } \\
\text { Walker \& Nader (1975) } \\
\text { Walker \& Nader (1975) } \\
\text { J. C. Mathers \& E. M. } \\
\text { Aitchison (unpublished } \\
\text { results) }\end{array}$ \\
\hline
\end{tabular}

* From Egan et al. (1975). † From Table 5.

butyrate, whereas others have reported greater efficiency with low acetate:propionate values (Hume, 1970; Ishaque et al. 1971; Jackson et al. 1971; Kennedy \& Milligan, 1978) or conversely greater efficiency with high acetate: propionate values (Harrison et al. 1975, 1976).

Harrison et al. $(1975,1976)$ and Kennedy et al. $(1976)$ reported that increased microbial growth efficiency was related to increased dilution rate of rumen fluid (D) but no such relationship was apparent in the present experiment nor in a review of published values covering a range of concentrate-forage diets (Mathers, 1978). In vitro continuous culture experiments with rumen bacteria have shown that increasing $D$ (which under these conditions is equivalent to the specific growth rate $(\mu)$ ) within limits increases the yield of bacterial cells (Hobson, 1965; Hobson \& Summers, 1967) and a mathematical relationship between $\mu$ and $Y_{\text {ATP }}$ has been proposed (Stouthamer, 1977). The lack of relationship between D and $Y_{\mathrm{ATP}}$ in vivo may be explained if $\mathrm{D}$ is a poor estimate of $\mu$. In view of the known colonization of food particles by bacteria, it is not unexpected that microbes could be sequestered in the rumen and remain there longer than solute markers (Mathison \& Milligan, 1971; Faichney \& Griffiths, 1978) and a review of published values has shown that in vivo estimates of the specific growth rate $(\mu)$ of rumen micro-organisms, calculated where necessary from the original values, are lower than corresponding estimates of $D$ based on water-soluble markers (Table 8). The relationship, if any, between $\mu$ and $D$ is unknown.

The present experiment has revealed that the energetic efficiency of microbial $\mathrm{N}$ yield can vary significantly with diet and that some of this variation is explained by a shift in the proportion of ATP used for synthesis of non-protein DM. However, the synergistic effect of dietary components on $Y_{\mathrm{ATP}}$ remains. It is possible that the latter results from variation in the specific growth rate of rumen micro-organisms $(\mu)$. Since $\mu$ may be directly determined using isotopic markers such as ${ }^{35} \mathrm{~S}$ or ${ }^{15} \mathrm{~N}$, further studies on the influence of diet on $\mu$ may aid our understanding of variation in microbial growth efficiency (Hespell \& Bryant, 1979).

\section{Degradation of dietary protein}

Reliable estimates of the degradability of food protein in the rumen are difficult to obtain because undegraded food NAN which is often a relatively small proportion of total NAN flow is usually determined indirectly by difference and is subject to an accumulation of errors. However, when these values are re-expressed as degradability of food protein, i.e. 
1-proportion of food protein escaping degradation, the precision of these estimates is more acceptable (Miller, 1978).

Estimates of food protein degradability obtained using ${ }^{35} \mathrm{~S}$. The procedure used to fractionate duodenal digesta NAN in this study was sufficiently precise to detect a linear change in degradability as the proportion of barley protein in the diet increased (Table 6) and it appeared that food protein degradabilities were additive. The estimated degradability of lucerne protein $(0.72)$ was a little lower than those $(0.79,0.79$ and 0.80$)$ calculated from the results of Pilgrim et al. (1970), Lindsay \& Hogan (1972) and Nolan \& Leng (1972) respectively but much higher than that $(0 \cdot 48)$ calculated from the combined results of Egan et al. (1975) and Walker et al. (1975). It has long been recognized that, e.g. heat treatment reduces the degradability of food protein in the rumen (Chalmers et al. 1954) and it is possible that differences in the extent of post-harvest processing could have led to the wide range $(0.48-0.80)$ in estimates of lucerne-protein degradability but undoubtedly technical differences and experimental errors were also involved. Estimates of barley-protein degradability are few. Ling \& Buttery (1878) reported values of 0-89-1.0 in good agreement with the value of 0.86 (Table 4) obtained in the present study. The results of Mercer et al. (1980) suggest a similar high degradability for barley protein in contrast to a value of 0.72 calculated from Mathison \& Milligan (1971). In the latter study, NAN flow to the SI was unusually high in relation to $\mathrm{N}$ ingested and the procedures used to fractionate $\mathrm{NAN}$ leaving the rumen were tentative.

The polyester bag technique. Recently there has been considerable interest in developing simpler procedures for estimating food protein degradability and the use of synthetic fibre (Dacron or polyester) bag techniques (Ørskov \& Mehrez, 1977; Mathers et al. 1977) has been widely canvassed. A major obstacle in applying such techniques has been the extraction of a degradability value from the curves of disappearance of food protein from the bags during incubation in the rumen. Mathers et al. (1977) suggested that for protein concentrates, degradability corresponded with the disappearance of $N$ from the bags after $4-6 \mathrm{~h}$ incubation while for basal feeds, Ørskov \& Mehrez (1977) calculated degradability as N disappearance when $90 \%$ of digestible DM had disappeared. More recently, Ørskov \& McDonald (1979) have proposed a procedure which combines a mathematical description of food $\mathrm{N}$ disappearance from the bags with a fractional rate constant for passage of undegraded food protein from the rumen; analogous models have been used by Blaxter et al. (1956), Waldo et al. (1972) and Broderick (1978) to describe DM and cellulose digestion in vivo and protein degradation in vitro. The present experiment provided the first opportunity to make a direct comparison between estimates of protein degradability determined conventionally by analysis of duodenal digesta with independent estimates derived from simultaneous polyester bag experiments.

Comparison of ${ }^{35} S$ and polyester bag values. Orskov \& Mehrez's (1977) proposal (model A on p. 590) that protein degradability corresponds with the proportion of $\mathrm{N}$ disappearing when $90 \%$ of digestible DM has disappeared from the bag gave consistently low estimates of degradability (Table 6). Calculation of food protein degradability using values from polyester bag experiments and models $B$ and $C$ (see p. 590) requires information on the fractional rate of outflow of undegraded protein from the rumen $\left(k\right.$ or $\left.k_{r}\right)$. This parameter was not measured in the present experiment and instead, $k$ and $k_{r}$ were assumed to be 0.046 i.e. $k$ estimated by Ganev $e t$ al. (1979) for Cr-treated soya-bean particles placed in the rumen of sheep consuming dried grass at approximately the maintenance level of feeding. This seems a reasonable approximation as $k$ values of $0.03-0.067$ have been reported for whole barley grain-fed sheep (Ganev et al. 1979; Mehrez et al. 1980) and a mean of 0.052 may be calculated for sheep given chaffed lucerne by Grovum \& Williams $(1973 a, b ; 1977)$. In addition, theoretical calculations were carried out to assess the effects 


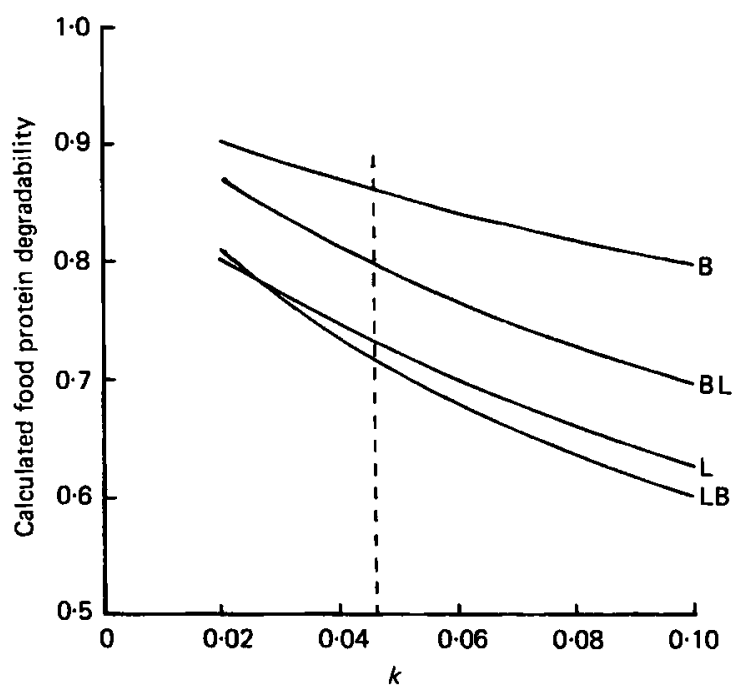

Fig. 3. Graphical presentation of the results from calculations of the effects of variation in fractional outflow rate of undegraded protein from the rumen $(k)$ on estimates of the degradability of protein (non-urea-nitrogen) in all lucerne (L), lucerne-barley $(2: 1 ; \mathrm{LB})$, barley-lucerne $(2: 1$; BL) and all barley (B) diets in the rumen of sheep. For details of diets, see p. 588. Food protein degradability was calculated as described by Ørskov \& McDonald (1979) (model B on p. 590) for each diet using values for parameters $a, b$ and $c$ given in Table 5 and values of $k$ between 0.02 and $0 \cdot 10$. For calculations reported in Table $6, k$ was assumed to be 0.046 .

of varying $k$ over a wide range on estimates of protein degradability using Ørskov \& McDonald's (1979) procedure (model B on p. 590). The results displayed graphically in Fig. 3 show that over the probable range of $k$ for sheep given lucerne and barley at maintenance $(0.04-0.06)$, food protein degradability will be altered by only $0.03-0.06$ units. The results further indicate that manipulations which increase $k$, e.g. increased level of feeding are likely to have their greatest effects where $c$, the rate-constant for disappearance of $\mathrm{N}$ from the polyester bag, is smallest.

Estimates of food protein degradability obtained from the ${ }^{35} \mathrm{~S}$ procedure and from polyester bag values models B and C (Ørskov \& McDonald, 1979; Miller, 1980; see p. 600) when $k$ or $k_{r}$ is assumed to be 0.046 were remarkably similar (Table 7). Such good agreement between two independent techniques for estimating protein degradability increases confidence in the use of either but of course it is not proof that the techniques are measuring this parameter accurately. For these foods, our simpler calculation (model C; Miller, 1980) which does not require sophisticated computational facilities gives similar degradabilities to that of Ørskov \& McDonald (1979) but this may not always be the case.

We suggest that if possible others should carry out concurrent polyester bag experiments when undertaking conventional studies to measure food protein degradability under various circumstances so that a better test of the validity of using this simpler procedure may be made.

The authors thank D. E. Walters (ARC Statistics Group, Cambridge) for statistical advice, N. W. Galwey (Department of Applied Biology, Cambridge University) for assistance with computing and the Northern Ireland Department of Agriculture for a postgraduate studentship awarded to J.C.M. 


\section{REFERENCES}

Agricultural Research Council (1965). The Nutrient Requirements of Farm Livestock no. 2, Ruminants. London: HM Stationery Office.

Allen, S. A. \& Miller, E. L. (1976). Br. J. Nutr. 36, 353.

Allison, M. J. (1965). In Physiology of Digestion in the Ruminant, p. 369 [R. W. Dougherty, editor]. London: Butterworths.

American Society of Agricultural Engineers (1967). Yb. Am. Soc. agric. Engrs., p. 301.

Ash, R. W. (1962). Anim. Prod. 4, 309.

Barker, S. B. \& Summerson, W. H. (1940). J. biol. Chem. 138, 535.

Blaxter, K. L., Graham, N. Mc. C. \& Wainman, F. W. (1956). Br. J. Nutr. 10, 69.

Bray, A. C. \& Till, A. R. (1975). In Digestion and Metabolism in the Ruminant, p. 243 [I. W. McDonald \& A. C. I. Warner, editors]. Armidale, Australia: University of New England Publishing Unit.

Broderick, G. A. (1978). J. Nutr. 108, 181.

Chalmers, M. I., Cuthbertson, D. P. \& Synge, R. L. M. (1954). J. agric. Sci., Camb. 44, 263.

Chamberlain, D. G. \& Thomas, P. C. (1979). J. Sci. Fd Agric. 30, 677.

Church, D. C. (1975). Digestive Physiology and Nutrition in Ruminants, vol. I, 2nd ed. Oregon, U.S.A.: D.C. Church.

Czerkawski, J. W. (1976). J. Sci. Fd Agric. 27, 621.

Donaghey, S. F. O'B. (1976). Metabolic pathways in whole animals: A quantitative study of glucose metabolism in ruminants with special reference to lactating cows. PhD Thesis, University of Cambridge.

Downes, A. M. \& McDonald, I. W. (1964). Br. J. Nutr. 18, 153.

Egan, A. R., Walker, D. J., Nader, C. J. \& Storer, G. (1975). Aust. J. agric. Res. 26, 909.

Faichney, G. J. \& Griffiths, D. A. (1978). Br. J. Nutr. 40, 71.

Ganev, G., Ørskov, E. R. \& Smart, R. (1979). J. agric. Sci., Camb. 93, 651.

Gawthorne, J. M. \& Nader, C. J. (1976). Br. J. Nutr. 35, 11.

Grovum, W. L. \& Williams, V. J. (1973a). Br. J. Nutr. 30, 231.

Grovum, W. L. \& Williams, V. J. (1973b). Br. J. Nutr. 30, 313.

Grovum, W. L. \& Williams, V. J. (1977). Br. J. Nutr. 38, 425.

Hagemeister, H., Lupping, W. \& Kaufmann, W. (1981). In Recent Advances in Animal Nutrition - 1980, p. 67 [W. Haresign, editor]. London: Butterworths.

Harrison, D. G., Beever, D. E., Thomson, D. J. \& Osbourn, D. F. (1975). J. agric. Sci., Camb. 85, 93.

Harrison, D. G., Beever, D. E., Thomson, D. J. \& Osbourn, D. F. (1976). J. Sci. Fd Agric. $27,617$.

Harrop, C. J. F. (1974). J. agric. Sci., Camb. 83, 249.

Hespell, R. B. \& Bryant, M. P. (1979). J. Anim. Sci. 49, 1640.

Hobson, P. N. (1965). J. gen. Microbiol. 38, 167.

Hobson, P. N. \& Summers, R. (1967). J. gen. Microbiol. 47, 53.

Hume, I. D. (1970). Aust. J. agric. Res. 21, 297.

Hume, I. D. \& Bird, P. R. (1970). Aust. J. agric. Res. 21, 315.

Ishaque, M., Thomas, P. C. \& Rook, J. A. F. (1971). Nature, New Biol. $231,253$.

Jackson, P., Rook, J. A. F. \& Towers, K. G. (1971). J. Dairy Res. 38, 33.

Johnson, C. M. \& Nishita, H. (1952). Analyt. Chem. 24, 736.

Journet, M. \& Vèrité, R. (1977). In Protein Metabolism and Nutrition, p. 119 [S. Tamminga, editor]. Wageningen: Centre for Agricultural Publishing and Documentation.

Kennedy, P. M., Christopherson, R. J. \& Milligan, L. P. (1976). Br. J. Nutr. 36, 231.

Kennedy, P. M. \& Milligan, L. P. (1978). Br. J. Nutr. 39, 105.

Leng, R. A. (1970). In Physiology of Digestion and Metabolism in the Ruminant, p. 406 [A. T. Phillipson, editor]. Newcastle-upon-Tyne: Oriel Press.

Leng, R. A. (1973). In Chemistry and Biochemistry of Herbage, vol. 3, p. 81 [G. W. Butler and R. W. Bailey, editors]. New York: Academic Press.

Lindsay, J. R. \& Hogan, J. P. (1972). Aust. J. agric. Res. 23, 321.

Ling, J. R. \& Buttery, P. J. (1978). Br. J. Nutr. 39, 165.

McAllan, A. B. \& Smith, R. H. (1974). Br. J. Nutr. 31, 77.

McAllan, A. B. \& Smith, R. H. (1977). Br. J. Nutr. 37, 55.

McDonald, I. W. (1948). J. Physiol., Lond. 107, 21 P.

McMeniman, N. P., Ben-Ghedalia, D. \& Armstrong, D. G. (1976). In Protein Metabolism and Nutrition, p. 217 [D. J. A. Cole, K. N. Boorman, P. J. Buttery, D. Lewis, R. J. Neale and H. Swan, editors]. London: Butterworths.

MacRae, J. C. \& Armstrong, D. G. (1969). Br. J. Nutr. 23, 377.

Mann, S. O. (1970). J. appl. Bact. 33, 403.

Mason, V. C. (1969). J. agric. Sci., Camb. 73, 99.

Mathers, J. C. (1978). Inter-relationships between energy and protein metabolism in the rumen. PhD Thesis, University of Cambridge.

Mathers, J. C., Horton, C. M. \& Miller, E. L. (1977). Proc. Nutr. Soc. 36, 37A. 
Mathers, J. C. \& Miller, E. L. (1977). Proc. Nutr. Soc. 36, 7A.

Mathers, J. C. \& Miller, E. L. (1980). Br. J. Nutr. 43, 503.

Mathison, G. W. \& Milligan, L. P. (1971). Br. J. Nutr. 25, 351.

Mehrez, A. Z., Ørskov, E. R. \& McDonald, I. (1977). Br. J. Nutr. 38, 437.

Mehrez, A. Z., Ørskov, E. R. \& Opstvedt, J. (1980). J. Anim. Sci. 50, 737.

Mercer, J. R., Allan, S. A. \& Miller, E. L. (1980). Br. J. Nutr. 43, 421.

Miller, E. L. (1978). In Ruminant Digestion and Feed Evaluation, p. 15.1 [D. F. Osbourn, D. E. Beever and D. J. Thomson, editors]. London: Agricultural Research Council.

Miller, E. L. (1980). In Vicia Faba. Feeding Value, Processing and Viruses, p. 17 [D. A. Bond, editor]. The Hague: Martinus Nijhoff.

Nolan, J. V. \& Leng, R. A. (1972). Br. J. Nutr. 21, 177.

Offer, N. W., Axford, R. F. E. \& Evans, R. A. (1978). Br. J. Nutr. 40, 35.

Ørskov, E. R., Fraser, C. \& McDonald, I. (1971). Br. J. Nutr. $26,477$.

Ørskov, E. R. \& McDonald, I. (1979). J. agric. Sci., Camb. 92, 499.

Ørskov, E. R. \& Mehrez, A. Z. (1977). Proc. Nutr. Soc. 36, 78A.

Pearson, R. M. \& Smith, J. A. B. (1943). Biochem. J. 37, 148.

Pennington, R. J. \& Sutherland, T. M. (1956). Biochem. J. 56, 353.

Phillipson, A. T. (1952). Br. J. Nutr. 6, 190.

Phillipson, A. T. (1964). In Mammalian Protein Metabolism, vol. 1, p. 71 [H. N. Munro \& J. B. Allison, editors]. London: Academic Press.

Pilgrim, A. F., Gray, F. V., Weller, R. A. \& Belling, C. B. (1970). Br. J. Nutr. 24, 589.

Ridgman, W. R. (1975). Experimentation in Biology, p. 101, Glasgow and London: Blackie.

Rowell, J. G. \& Walters, D. E. (1976). J. agric. Sci., Camb. 87, 423.

Roy, J. H. B., Balch, C. C., Miller, E. L., Ørskov, E. R. \& Smith, R. H. (1977). In Protein Metabolism and Nutrition, p. 126 [S. Tamminga, editor]. Wageningen: Centre for Agricultural Publishing and Documentation.

Satter, L. D. \& Roffler, R. E. (1977). In Protein Metabolism and Nutrition, p. 133 [S. Tamminga, editor]. Wageningen: Centre for Agricultural Publishing and Documentation.

Singh, U. B., Varma, A., Verma, D. N., Lal, M. \& Ranjhan, S. K. (1973). J. agric. Sci., Camb. $81,349$.

Stephen, A. M. \& Cummings, J. H. (1979). Proc. Nutr. Soc. 38, 141 A.

Stephen, A. M. \& Cummings, J. H. (1980). J. med. Microbiol. 13, 45.

Stouthamer, A. H. (1977). In Microbial Energetics, p. 285 [B. A. Haddock and W. A. Hamilton, editors]. London: Cambridge University Press.

Sutton, J. D. \& Johnson, V. W. (1969). J. agric. Sci., Camb. 73, 459.

Thivend, P. \& Journet, M. (1968). Annls Biol. anim. Biochem. Biophys. 8, 449.

Thomas, P. C. (1973). Proc. Nutr. Soc. 32, 85.

Thomson, D. J., Beever, D. E., Coelho da Silva, J. F. \& Armstrong, D. G. (1972). Br. J. Nutr. 28, 31.

Ulbrich, M. \& Scholz, H. (1963). Arch. Tierernähr. 13, 296.

Ulbrich, M. \& Scholz, H. (1966). Arch. Tierernähr. 16, 325.

Wainman, F. W. (1977). Proc. Nutr. Soc. 36, 195.

Waldo, D. R., Smith, L. W. \& Cox, E. L. (1972). J. Dairy Sci. 55, 125.

Walker, D. J., Egan, A. R., Nader, C. J., Ulyatt, M. J. \& Storer, G. B. (1975). Aust. J. agric. Res. 26, 699.

Walker, D. J. \& Nader, C. J. (1968). Appl. Microbiol. 16, 1124.

Walker, D. J. \& Nader, C. J. (1975), Aust. J. agric. Res. 26, 698. 